Przegląd Badań Edukacyjnych Educational Studies Review

ISSN 1895-4308

nr 35 (2/2021), s. 275-290

Bogusława Dorota Gołębniak

University of Lower Silesia, Wroclaw, Poland

e-mail: dorota.golebniak@wp.pl

ORCID: https://orcid.org/0000-0002-6163-5208
METODY ZBIERANIA

I ANALIZY DANYCH

W BADANIACH EDUKACYJNYCH

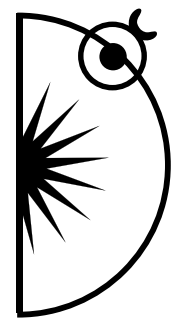

\title{
Refunctioning and Extending Ethnographic Methods of Data Collection and Analysis in Educational Action Research
}

http://dx.doi.org/10.12775/PBE.2021.043

\begin{abstract}
:
The paper discusses the effect of epistemological-methodological turns in the social sciences, including education and cultural anthropology, on our decisions when selecting and applying methods of data collection and analysis in educational action research. My assumption is that ethnographic description not only provides a starting point for most educational projects launched within this design of intervention research but also appears as a 'methodology' across their stages (in ongoing evaluation, which reveals what is happening and how it is happening in the educational situation as the intervention is being carried out, and in the final assessment, which determines the further development of the project). Given this, I focus on how the decision-making and implementation processes (can) reflect the extension of various forms of inquiry propelled by the refunctioning of ethnography in the aftermath of 'the crisis of representation.' My explorations revolve around the notion of transition (from to): the transition from Kurt Lewin's model to so-called research/practice in educational action research and the transition from description to performance regarding the application of ethnographic methods in action research. This also involves redefining the field, expanding the classic methods of data collection and analysis (= participant observation), and redrawing the status of the researcher and other project participants, which leads to the shift from ethnographic expertise to the ethnography of expertise.
\end{abstract}


Keywords: educational action research, transformational research/practices, refunctioned ethnography, extended observation and interview/document analysis, ethnography of expertise.

\section{Introduction}

Increasingly often undertaken in public space, educational action research accompanies and sometimes also determines the direction of bottom-up changes in 'hot' areas of broadly conceived education (Červinkova, 2013b; Krenz, 2013). Action research appears to have firmly established itself in teacher education and continuing professional development systems as well (Červinkova, 2013a; Czerepaniak-Walczak, 2014; Ligus, 2013). It is also more and more frequently chosen as the methodological framework of theses and dissertations submitted in pursuit of research degrees. Questions concerning the methodological 'correctness' of action-research strategies time and again crop up in sessions with academic advisors and in seminars and workshops devoted to action research. The fact that such doubts are articulated bespeaks dedication to the academic legitimacy of $\mathrm{MA} / \mathrm{PhD}$ projects and increasing awareness of the importance of their theoretical underpinnings.

Below, I share my reflections on the connections between contemporary versions of educational action research and the increasingly diversified modes of practising post-traditional ethnography. While my co-edited volume Badania $w$ działaniu. Pedagogika i antropologia zaangażowane [Action Research: Engaged Pedagogy and Anthropology] (Červinkova \& Gołębniak, 2010) looked into the shared areas of education and anthropology, two research discourses which tend to be developed separately in academia, in this paper I do not go into the details of distinctions between anthropology and ethnography, educational ethnography and ethnography of education, or its exclusive and inclusive frameworks (Gołębniak, 2017; Drozdowski, 2019). Instead, I focus on how socalled extended methods stemming from refunctioned ethnography 'work' or 'can work' in producing ethnographic descriptions not only at the onset but also across the further stages of educational action-research projects. In any case, the selection and application of these methods do not take place in a methodological void. Therefore, one must not ignore crises and conceptual shifts produced in overcoming those and prompting changes in approaches to research methodology. The adoption of a given version of post-traditional ethnography determines not so much the 'retooling'

${ }^{1}$ I borrow this term from Judith Sachs's paper on developing teachers' 'new' professionalism, among others, via teachers' action research (Sachs, 1999). 
the model of being with others in the world of the project launched to change the educational situation, as this version comes with its methodological orientation that defines the status of the researcher and other project participants and thus situates the findings on the continuum between ethnographic expertise and the ethnography of expertise.

Building on these observations, I make the eponymous concepts of refunctioning and extension, which, as shown further in this paper, originate both in post-traditional ethnography and in educational action-research methodology, the axis of my argument. To begin, I briefly outline the context, essence and changing models of educational action research. Subsequently, I discuss how 'engaged ethnographic approaches' (situated within so-called refunctioned ethnography) can contribute to this kind of inquiry. I argue that the selection of 'extended' techniques of data collection and analysis co/determines the shape of the project by defining the position of the researcher and other participants, relations between them, the form of representation and the culture of 'expertise.' In conclusion, I offer a tentative typology of interconnections between contemporary versions of educational action research and respective approaches in engaged ethnography.

\section{From Kurt Lewin to transformative research/practices: the context/s, essence and evolution of action research}

Debates on how far and in what ways the methods of data collection and analysis affiliated with ethnography as an autonomous discipline can be employed in action research unfold in a special historical, social, political, cultural, methodological and didactic context. We are witnessing an exacerbation of problems that prompt the social sciences to engage with the challenge of what Norman Denzin and Yvonna Lincoln portray as a ressourcement, (resumption of an ancillary role in society) in their 'Introduction' to the Handbook of Qualitative Research (Denzin \& Lincoln, 2005). The world that we have so far believed familiar and well-examined is falling apart as we speak of it. The pandemic and post-pandemic developments, with their implications for politics, socio-cultural life (Koczanowicz, 2020; Król, 2020; Żiżek, 2020) and education (Pyżalski, 2020), make it expedient to reflect on (arrogant though it may sound) how educators can foster and spread competencies for developmental research of all kinds, including the designs that directly combine action and inquiry. Such pedagogical intervention appears all the more urgent since the social transformations that commentators commonly believe the COVID-19 pandemic has 
revealed as acutely imperative include reindustrialisation, a revival of democratic values, ecological investment, the interlocking of communities by coercion with communities by compulsion and a bottom-up 'revolution' in the schooling system with teachers and students envisaged as 'designers' of education. ${ }^{2}$

Developed since the mid- $20^{\text {th }}$ century, action research differs from conventional qualitative and quantitative studies in that it is conducted within the social system (rather than into or on it) and as such takes the form of a specific, critically-inspired social action. It unfolds as experimentation in which researchers and practitioners collaboratively work to develop a solution to a 'burning' problem in directly experienced everyday life. Since Kurt Lewin's foundational studies (Lewin, 1946), action research, in which action, inquiry and education are brought together in a triangular arrangement, has been carried out in a spiral sequence: research - planning - implementation along with accompanying inquiry - modification - final evaluation... and the next cycle of the procedure. Following the postmodernist turn as a response to the constraints of positivism and embedded in interpretivism, action research characteristically situates its explorations in a broad context, is future-oriented (so-called projects of possibilities) and agnostic, involves collaborative action across its stages and generates its findings in the form of action-grounded theory. Action research, which was involved in bottom-up recasting of school curricula (in Anglophone, Dutch and Danish settings) in the 1980s, was conducted in two models: practical-deliberative and critical-emancipatory. While these models somewhat differed in their theoretical anchoring (interpretive sciences and constructivism vs. critical theories), frameworks of professionalism (reflective practitioner vs. transformative intellectual) and attitudes to change (revitalisation vs. transformation), both retained the classic Lewinian structure and investigated their context of action by means of ethnographic description (Gołębniak, 2019). In the course of time, action research lost some of its innovative cutting-edge quality as its institutionalisation inevitably entailed considerable bureaucratisation (Sachs, 1999). This discourse was reinvigorated when the action turn took place in the methodology of social research (Heron \& Reason, 1997; Torbet \& Reason, 2001). In the aftermath of the action turn, research discourse again emphasised the relevance of reflective knowledge, critical mindset and communal inquiry to launching bottom-up social change; it also surmounted the dichotomy of (tensions be-

2 An important point of reference in this context is provided by Alex Burow's Schule digital - wie geht das? Wie die digitale Revolution uns und die Schule verändert, discussed by Bogusław Śliwerski in his blog on $21^{\text {st }}$ September 2020. 
tween) two mainstream methodologies: empirical positivism and postmodernist interpretivism. In this way, it encouraged reaching beyond description (and interpretation) in practical research. In the new paradigm ('transformational social science'), investigations are no longer about constructing and deconstructing the research project but about how to be/act in everyday life 'whether or not [...] the evidence is not clear,' as Peter Reason and William Torbet put it (2001, p. 6). Stepping beyond the linguistic turn is thus expressed in commitment to inquiry-in-action and fostering communities within a community. The redefined goal of science is achieved in developing practical knowledge embodied in research and emerging from the collaborative relations of people who jointly explore the world, participate in a broader setting and experience their presence in their own worlds. This knowledge takes the form of a species of normative theory that determines 'what act is timely in the present' (Reason \& Torbet, 2001, p. 15).

The expanded model of knowledge is supported by the re-constructed and more comprehensive typology of research paradigms charted by Egon Guba and Yvonna S. Lincoln in the Handbook of Qualitative Research (Guba \& Lincoln, 2005). Besides, positivism, post-positivism, critical theories and constructivism, this typology also includes the 'participatory paradigm,' which is founded on subjective-objective ontology and extended epistemology that recognises experiential, presentational, propositional and practical modes of knowing, ${ }^{3}$ a methodology, we can add, which is based on cooperative relations among coresearchers and on an axiology affirming the primary value of practical knowledge and which, as such, is supposed to be of direct service to people. This 'living' knowledge is accumulated in research communities rooted in communities of practice. It is manifest both in researchers' conscious, self-reflective action and in the secondary, though carefully acknowledged, background voices, such as theories (which provide analytic categories and interpretive keys to shed light on what is happening and how), narratives (other than those that appear obvious from the viewpoint of research objectives) and artefacts (from the sphere of art). Co-researchers are introduced into the process by mediators who trigger processes of learning through active involvement in the process and attention to the formation of democratic personalities and skills (Guba \& Lincoln, 2005).

${ }^{3}$ Without a good equivalent in Polish, knowing (literally: wiedzenie) is a concept used in the discourse of practical inquiry to bring into relief the form and nature of knowledge inscribed, as it were, in practical pursuits, which is not necessarily consciously recognised or, even less, verbalised. 


\section{Transformational science as research/practice}

1. Integration of inquiry and practices in everyday professional and personal activities;

2. Pre-eminence of practical 'knowing' (embodied in the researcher/practitioner's step-by-step action for the development of humanity);

3. Participatory nature of 'knowing' (relations among people and communities);

4. Underpinned by the sensitive, sentient, thinking and experimenting presence of people in their worlds;

5. All moments of attention, knowing, acting and evidence collection and analysis contribute at the final stage to the production of a normative theory of that which is happening at the moment.

The importance attributed to knowing and other constitutive components of this framework (participatory relations, experimental grounding, normative theory) are reflected in new terminology. The term 'action research' is replaced by 'research/practice,' a moniker that refers to three types of projects grouped according to their scale. Specifically, they are first-person, second-person and third-person research/practices. The first-person type concerns the researcher's ability to critically examine his/her own goals and approaches along with the nature, results and effects of action, to foster his/her own theory of life and to improve the quality of his/her practices. Second-person research/practice is understood as helping organisations achieve a better self-understanding and develop a capacity to transform into knowledge organisations and to perfect their communication with their environments. Third-person research/practice is geared to reinforcing broad social change (Reason \& Torbet 2001).

\section{Refunctioned Ethnography: expanding the range of possible possibilities}

The relevance of ethnography to educational action research, which is often focused on changing school- or teaching culture, appears self-evident. In the classical model, the role of ethnography tends to be perceived in terms of a 'toolbox.' Its contents (i.e. methods and techniques of field research, that is, participant observation, analysis of journal records, thick description, etc.) are used to produce an account of an educational situation in which something 'doesn't work' and which consequently calls for a remedial action or for revising the practices in place. Ethnographic description is treated as a constant 'element 
of the game' and fixed within pre-defined limits. ${ }^{4}$ In this section, I argue that contemporary ethnography - which is affected by the turns that take place in the social sciences, faces its own crises and experiences its own shifts - is by no means homogeneous and that its coupling with selected approaches or concepts which redefine research practices along with the role of the researcher, the researched and the 'public,' can meaningfully determine the stages of the research procedure beyond the initial description of the site of educational research/action.

Given the current status of ethnography as produced by the shifts from the structural-functionalist model to ongoing remodellings in the wake of the crisis of representation, decision-making on the application of 'ethnographic methods' in educational action research should begin from 'sensitising' questions, such as: What do we need ethnographic methods for? What role is ethnography supposed to play in our project? Whom is it supposed to 'enable' and for what? Given the answers to these questions, what ethnographic framework should we build on? What are the methodological and educational consequences of specific theoretical positions developed within it? What opportunities and limitations are implicated in the application of redefined research methods? How do they determine the positions of project participants? What about their expertise? Who is or can be an expert while being involved in the project and in what scope? How about the forms of knowledge being developed? Should they only be treated as complementing the previous 'non-expertise' in dealing with the problems addressed?

\section{From 'Argonauts' to 'Writing Culture' or, Going beyond Malinowski}

Relinquishing functionalist-structural anthropology as embraced by Bronisław Malinowski, Alfred Radcliffe-Brown, Claude Lévi-Strauss, and their like, changes in the modes of practising anthropology were primarily triggered by a critique of anthropology offered in Writing Culture (Clifford \& Marcus, 1986). If traditional ethnography, which demanded the focalisation of research, the embedment of research in the field and attention to who says what, addressed issues of intersubjectivity from the position of interpretive power (claims to ethnographic authority) and gave precedence to representations, symbols, ini-

${ }^{4}$ Besides this version, there is also participatory action research, which is based on nonethnographic methods of data collection and analysis (stemming from both qualitative, for example phenomenological, and quantitative designs). The focus on diagnosis rather than on ethnographic description permits eclecticism as well. 
tiation rites and the method (Malinowski, 2005), since Writing Culture, the issues of power and knowledge have come to the fore in the discourse. They have become an object of study on equal footing with the typically ethnographic representations of everyday life, which are the favourite themes of classic ethnography (Holmes \& Marcus, 2005). Reflective critical anthropology no longer regards distance as fundamental in the researcher's attitude. Rather, its reconsidered version insists on producing reflective descriptions and interpretations of cultural phenomena (Marcus, 2002). With time, alternative conceptions of the role of ethnography are challenged by the discourse and rhetoric of moral liberation. Moreover, the oscillation between experimentation and activism appears to breed para-ethnography, where the Others (rather than professional researchers) are cast as experts (in matters of their own cultures, of course).

\section{From Textual Ethnography to Performative Ethnography}

Efforts to reach 'beyond Malinowski's ethnography' have produced a panoply of frameworks, including narrative ethnography, critical ethnography, performative ethnography, public ethnography, autoethnography, online ethnography and para-ethnography. All of them refunction classic ethnographic methods, and some (e.g. performative and online ethnographies) also generate new ones of their own. In narrative and critical approaches, long-term engagement in the culture of a community authorises focus on an individual or a limited number of people. Essentially, the researcher and those under study are presented together - within one polyvocal text relating how the encounter with another human being unfolded and capturing the nature of this process. One's own 'entry,' subjectivism, etc. are scrutinised as well (Chase, 2005). This dimension is central to autoethnography, in which the researcher him/herself is the object of study as s/he compiles and analyses inter-narratives. Usually carried out in conformity with the idea of 'making the personal political' (Holman-Jones, 2005), autoethnography attends to both routine and problematic experiences, but studies representations rather than experiences themselves (with writing treated as a form of representation). For its own part, performative ethnography seeks to 'show rather than tell.' It pivots on the primary concept of impossible encounters of possibility. This notion exemplifies the coupling of a critical-emancipatory approach and new structures of cultural politics (with research viewed as a catalyst of change). Performative ethnography profusely draws on Denzin's conception that political acts are simultaneously political and pedagogical (the pedagogical is politicised and the political is pedagogised) (Denzin, 2003). 
Traditional ethnography vs. refunctioned ethnography: major distinctions and shifts

If a prolonged stay in an area involving one or another form of engagement with the local community's culture lies at the core of ethnography as such, further stages of the research procedure (in terms of their paradigmatic affiliation) depend on answers to the questions posed on arrival: What do I do now? How do I start the fieldwork [...]? How do I engage the human subjects who can enliven my research and make my theoretical ideas anthropological? (Holmes \& Marcus, 2005, p. 1102). Various 'politics of practising' that establish relations between the researcher and the researched entail different forms of representation and attitudes to the 'public.'

From the ethnography of elites (Marcus, 1983) and the crisis of representation to the ethnography and expertise

The work of Bronisław Malinowski is associated with the notion of mise en scène. He used the term to denote the 'staging perception' of fieldwork (Malinowski, 2005). According to the co-authors of the study discussing the crisis of representation in the 1980s and the 'situation just before the crisis' regarding the research site (Holmes \& Marcus, 2005), while the dramaturgical crux of fieldwork remains the same, its scene changes. In the currently launched projects, the setting rarely resembles that of the Trobriand Islands. 'Being there' increasingly frequently means studying yet-unexplored or differently known places...in one's vicinity.

The participation of the Others in the project is also differently defined. The inferior role of the researcher's helpers/informants (referred to as natives or members of indigenous cultures) is re-cast into the subjective co-participation of individuals viewed as experts in their own culture, who are engaged not only at the stage of data collection but also in data analysis. Research participants are actors that actively contribute to the formation of that which is researched. Since, in this way, 'representation' is incorporated into research whose goals ensue from engagement in relations, what happens can be termed a transition from the ethnography of elites (Marcus, 1983) and the crisis of representation to the ethnography of expertise.

Conventional methods of data collection and analysis have been augmented. After the critiques offered by James Clifford and Clifford Geertz, participant observation can be both descriptive and oriented 'to,' inclusive of 'something,' fostering and also affirming membership identity (of a community member). Its field is demarcated by issues of ethics, values, the 'progressive social agenda.' 
Besides descriptive observation, researchers can rely on oriented observation and even, with a broad spectrum of possible forms of participation in the project, on selective observation. The study may focus on a peripheral member of a group, its active members or the entire membership (Angrosino, 2005). Methods for analysing talk and text have been similarly extended by incorporating forms that reach beyond objective thinking. Data registering and analysis techniques, including digital recording, are proving particularly pertinent as they expand access possibilities to naturally occurring - 'uncontrived' - data (e.g. recording teacher-parent conferences instead of interviewing teachers and/ or parents on what was said and how it was said during these conversations) (Peräkylä, 2005).

Evidently, the position of the researcher has been radically rethought in this research context. The researcher's status is determined by the way in which expert-roles are executed in joint inquiries. The 'control' of respective stages of the project implementation encompasses constant effort to construct frames of theorising and retheorising, to establish rules for the negotiation and renegotiation of meanings and to share voice/voices and the stage (not only of publishing as, besides reports, other forms of dissemination are allowed as well). Understood as assuming a critical perspective on the social life of 'common people,' the capacity to go beyond facilitation (Paolo Freire's concept of conscienti$z a c ̧ a \tilde{o})$ is aligned with the ability to experience the self as both the researcher and the respondent, the teacher and the student, and to explore the self within the process of inquiry (the self in research, as well as the brought-in self, the situationally generated self, etc.).

\section{Challenges}

The extending of methods promotes multidimensional research and poses 'concrete' challenges related to the principles of validity, completeness and systematicity. In this model, too, systematic ethnography must be understood as an internally ordered description of the generation and reproduction of learning worlds (and their socio-cultural dimensions). Although this description does not have to cover all the dimensions of these worlds, such as the systems of discourse, narration, material culture, aesthetics and performance, it should not ignore the criterion of completeness and comprehensively conceived adequacy. In this contexts, the point is that the world described should not consist exclusively of fieldnotes of conversations, interview narratives, visual artefacts and material goods. Another challenge is posed by the problematic aspects of the attitude referred to as 'fidelity to the phenomenon' and by the multiplicity of 
possible interpretations of the application of thick description (Geertz, 2005). Non-linguistic styles also call for attention. Their use requires not only reaching beyond the convention of diversity (Markham, 2005). That meeting all these methodological criteria is premised on educating researchers, especially nonprofessional ones as agents in action research, in the basics of the anthropology of education and/or educational anthropology appears indisputable. The threads and ideas evoked in this paper must be developed 'in action,' both through the study of the literature and through workshop-based practical exercises.

\section{Conclusion}

To come back to the questions driving my argument in this paper, an attempt can be made to propose a preliminary typological framework for ethnographic methodologies employed in and paradigmatically matching the various versions of action research. The reasoning above implies that its 'classic' designs aligned with Kurt Lewin's 'pure' model had their ethnographic counterpart in the traditional ethnographic description anchored in the structuralist-functionalist school of thought. Both practical-deliberative and critical-emancipatory action-research projects undertaken after the interpretive turn have often relied on reflective frameworks of refunctioned ethnography, such as autoethnography and narrative, public and performative ethnographies. The Polish literature abounds with studies that corroborate this insight (Siarkiewicz et al., 2012; Červinkova, 2013b; Ligus, 2013; Gołębniak, 2014). The adoption of the narrative ethnographical position and methodology is becoming an obvious choice for researchers who label their projects as transformational research/practice (Irasiak, 2017). I leave the questions of para-ethnography and eclecticism open (and to be addressed soon). Given the challenges of the future sparked in the present (see Introduction), I believe it makes sense to look into this approach, especially that it tends to be associated with activism. Activism is, on the one hand promoted in the education-scientific discourse on the teaching profession as a remedy to the bureaucratised model of teaching by touting the concept of a teacher-researcher of his/her own practice (see the works of authors embracing the ethical-altruistic perspective in the study of and research into professionalism; Cunningham, 2008). On the other, activism sparks reservations, as articulated by, for example Douglas R. Holmes and George Marcus, the cofounders of post-traditional cultural anthropology, who point out that activism is contingent and, hence, by definition controversial (Holmes \& Marcus, 2005). Undoubtedly, the emergence of a research model in which a new subject - an 
accomplished autodidact - appears is a compelling socio-cultural phenomenon. Spontaneously undertaken inquiry, which is bound up with concomitantly arising collaborative structures that confer the forms and content of ethnographic research on ensuing experience, poses profound questions about the condition of culture. To capture the salient features of unfolding changes and to conceptualise their multifarious aspects - in ways that, partly at least, depend on conventions, traditions and the past, while also accommodating the cognitive aspects of future-oriented practices - represent, without a doubt, intriguing challenges to and tasks for educators who aspire to augment the methodological underpinnings of their projects that, while inscribed in their disciplines, are geared to changing the status quo in teacher education or adult education.

\section{References}

Angrosino, M.V. (2005). Recontextualizing Observation: Ethnography, Pedagogy, and the Prospects for a Progressive Political Agenda. In: N.K. Denzin, \& Y.S. Lincoln (Eds.), The SAGE Handbook of Qualitative Research, 3ed. (pp. 729-747). Thousand Oaks-London-New Delhi: Sage.

Červinkova, H. (2013a). Etnografia edukacyjna i badania w działaniu [Educational Ethnography and Action Research]. Forum Oświatowe, 1(48), 123-137.

Červinkova, H. (2013b). Przywracając pamięć miastu: Z antropologiczno-pedagogicznych badań w działaniu [Reclaiming the Memory of the City: From Anthropological-Educatioal Action Research]. In: H. Cervinkova, \& B.D. Gołębniak (Eds.), Edukacyjne badania $w$ działaniu [Educational Action Research] (pp. 205-217). Warszawa: Scholar.

Červinkova, H. (Ed.) (2019). Antropologia i edukacja: Etnograficzne badania edukacyjne w tradycji amerykańskiej [Anthropology and Education: Ethographic Educational Research in American Ttradition]. Wrocław: Wydawnictwo Naukowe Dolnośląskiej Szkoły Wyższej.

Chase, S.E. (2005). Narrative Inquiry Multiple Lenses, Approaches, Voices. In: N.K. Denzin \& Y.S. Lincoln (Eds.), The Sage Handbook of Qualitatve Research: Third Edition (pp. 651-679). London-Thousand Oaks, CA-and New Dehi: Sage.

Clifford, J., \& Marcus, G.E. (Eds.) (1986). Writing Culture: The Poetics and Politics of Ethnography. Berkeley, Los Angeles-London: University of California Press.

Cunningham, B. (Ed.) (2008). Exploring Professionalism. London: Institute of Education. 
Czerepaniak-Walczak, M. (2013). Etyczne aspekty badania w działaniu: Poszanowanie praw uczestników badań [Ethical Apects of Action Research: Respecting the Rights of Research Participants). In: H. Cervinkova, \& B.D. Gołębniak (Eds.), Edukacyjne badania $w$ działaniu [Educational Action Research], (pp. 76-88). Warszawa: Wydawnictwo Naukowe Scholar.

Czerepaniak-Walczak, M. (2014). Badania w działaniu w kształceniu i doskonaleniu nauczycieli [Action Research in Teacher Education and Further Professional Training]. Przegląd Badań Edukacyjnych, 2(19), 181-94.

Denzin, N. (2003). Performance Ethnography: Critical Pedagogy and the Politics of Culture. Thousand Oaks-London-New Delhi: SAGE Publications.

Denzin, N., \& Lincoln, Y.S. (2005). Introduction: The Discipline and Practice of Qualitative Research. In: N.K. Denzin, \& Y.S. Lincoln (Eds.), The SAGE Handbook of Qualitative Research, 3 ed. (pp. 1-32). Thousand Oaks-London-New Delhi: Sage.

Drozdowski, J. (2019). Antropologia edukacji: Studium różnicy kulturowej w społeczeństwie otwartym [Anthropology of Education: on Cultural Difference in Open Society]. Poznań: Wydawnictwo Naukowe Wydziału Nauk Społecznych Uniwersyteu im. Adama Mickiewicza.

Geertz, C. (2005). Interpretacja kultury [originally published as The Interpretation of Cultures]. Transl. by M. Piechaczek. Kraków: Wydawnictwo Uniwersytetu Jagiellońskiego.

Gołębniak, B.D. (2013). Edukacyjne badania w działaniu - między akademicką legitymizacją a realizacyjnymi uproszczeniami [Educational Action Research: Between Academic Legitimisation and Practical Simpliifcations]. In: H. Cervinkova, \& B.D. Gołębniak (Eds.), Edukacyjne badania $w$ działaniu [Educational Action Research] (pp. 51-75). Warszawa: Wydawnictwo Naukowe Scholar.

Gołębniak, B.D. (2014). O „upedagogicznianiu” szkoły poprzez akademicki dyskurs edukacyjny: Ku autoetnografii [On 'Pedagogising' the School Through Academic Discourse on Education: Towards an Autoethnography]. Forum Oświatowe, 2(52), 147-169. Retrieved 20 June 2021 from: http://forumoswiatowe.pl/index.php/czasopismo/article/ view/279.

Gołębniak,B.D.(2019). Proces kształcenia[EducationalProcesses). In:Z.Kwieciński, \&B. Śliwerski (Eds.), Pedagogika. Podręcznik akademicki [Education: a University Textbook] (pp. 857-959). Warszawa: Wydawnictwo Naukowe PWN.

Gołębniak, B.D., \& Červinkova, H. (2010). W poszukiwaniu emancypacyjno-transformacyjnego wymiaru badań pedagogicznych i antropologicznych [Exploring the Emancipatory-Transformative Dimension of Educational and Anthropological Research]. In: H. Červinkova, \& B.D. Gołębniak (Eds.), Badania w działaniu: Pedagogika i an- 
tropologia zaangażowane [Action research: Engaged Pedagogy and Anthropology] (pp. VII-XVII). Wrocław: Wydawnictwo Naukowe Dolnośląskiej Szkoły Wyższej.

Gołębniak, B.D, \& Zamorska, B. (2020). Wyjść poza opis: Interwencje formatywne w edukacji dziecka [Beyond Description: Formative Interventions in Child Education). In: M. Magda-Adamowicz, \& E. Kowalska (Eds.), Dziecko i dzieciństwo w badaniach pedagogicznych [The Child and Childhood in Eeducation Research] (pp. 315-335). Toruń: Wydawnictwo Adama Marszałek.

Gołębniak, M. (2017). Antropologia i etnografia edukacyjna - na pograniczu dyscyplin [Anthropology and Educational Ethnography: At the Intersection of Disciplines). Forum Oświatowe, 29, 2(58), 45-60. Retrieved 25 June 2021 from: https://forumoswiatowe. pl/index.php/czasopismo/article/view/578.

Guba, E.G., \& Lincoln, Y.S. (2005). Paradigmatic Controversies, Contradictions, and Emerging Confluences. Competing Paradigms in Qualitative Research. In: N.K. Denzin, \& Y.S. Lincoln (Eds.), The SAGE Handbook of Qualitative Research, $3^{\text {rd }}$ ed. (pp. 191-218). Thousand Oaks-London-New Delhi: Sage.

Heron, J., \& Reason, P. (1997). A Participatory Inquiry Paradigm. Qualitative Inquiry, 3(3), 274-294.

Holman-Jones, S. (2005). Autoethnography: Making the Personal Political. In: N.K. Denzin, \& Y.S. Lincoln (Eds.), The SAGE Handbook of Qualitative Research, $3^{\text {rd }}$ ed. (pp. 763-792). Thousand Oaks-London-New Delhi: Sage.

Holmes, D.R., \& Marcus, G.E. (2009). Refunctioning Ethnography: the Challenge of an Anthropology of the Contemporary. In: N.K. Denzin, \& Y.S. Lincoln (Eds.), The SAGE Handbook of Qualitative Research, $3^{\text {rd }}$ ed. (pp. 1099-1114). Thousand Oaks-LondonNew Delhi: Sage.

Irasiak, A. (2017). Wzajemne uczenie się osób gluchych i słyszących w projekcie edukacyjnym [Mutual Learning of Deaf and Hearing People in an Educational project]. Unpublished PhD dissertation, Faculty of Education, University of Lower Silesia in Wrocław.

Koczanowicz, L. (2020). Lęk i olśnienie. Eseje o kulturze niepokoju [Anxiety and Lucidity: Essays on the Culture of Unrest]. Warszawa: Wydawnictwo Instytutu Badań Literackich PAN.

Krenz, R. (2013.) Pro et contra - głos krytyczny [Pro et Contra: A Critical Voice). In: H. Cervinkova, \& B.D. Gołębniak (Eds.), Edukacyjne badania w działaniu [Educational Action Research] (pp. 89-102). Warszawa: Wydawnictwo Naukowe Scholar.

Król, M. (2020). Notatki. Równość. Marzenie o wspólnocie [Notes. Equality. Dreaming of Community]. Retrieved 25 May 2020 from: https://obywatele.news/notatki-prof-marcina-krola-marzenie-o-wspolnocie/. 
Lewin, K. (1946). Action Research and Minority Problems. Journal of Social Issues, 2(4), 34-46.

Ligus, R. (2013) Tutoring uczestniczący w akademickim kształceniu nauczycieli jako badanie w działaniu [Participatory Tutoring as Action Research in Teacher University Education). In: H. Cervinkova, \& B.D. Gołębniak (Eds.), Edukacyjne badania w działaniu [Educational Action Research] (pp. 228-248). Warszawa: Wydawnictwo Naukowe Scholar.

Malinowski, B. (2005) Argonauci zachodniego Pacyfiku [originally published as Argonauts of the Western Pacific: An account of native enterprise and adventure in the archipelagoes of Melanesian New Guinea]. Transl. by B. Olszewska-Dyoniziak, \& S. Szynkiewicz. Warszawa: Wydawnictwo Naukowe PWN.

Marcus, G.E. (1983). Elites: Ethnographic Issues. Albuquerque: University of New Mexico Press.

Marcus, G.E. (2002). Beyond Malinowski and after Writing Culture: On the Future of Cultural Anthropology and the Predicament of Ethnography. The Australian Journal of Anthropology, 13(2), 191-199, doi: 10.1111/j.1835-9310.2002.tb00199.x.

Marcus, G.E., \& Fischer, M.J. (1986). Anthropology as Cultural Critique: an Experimental Moment in the Human Sciences. Chicago: University of Chicago Press.

Markham, A.N. (2005). The Methods, Politics, and Ethics of Representation in Online Ethnography. In: N.K. Denzin, \& Y.S. Lincoln (Eds.), The SAGE Handbook of Qualitative Research, $3^{\text {rd }}$ ed. (pp. 793-820). Thousand Oaks-London-New Delhi: Sage.

Peräkylä, A. (2005). Analyzing Talk and Text. In: N.K. Denzin, \& Y.S. Lincoln (Eds.), The SAGE Handbook of Qualitative Research, $3^{\text {rd }}$ ed. (pp. 869-886). Thousand Oaks-London-New Delhi: Sage.

Pyżalski, J. (2020). Zdalne nauczanie - gdzie jesteśmy, dokąd idziemy? Wstępne wyniki badań naukowych 'Zdalne nauczanie a adaptacja do warunków społecznych $w$ czasie pandemii koronawirusa' [Remote Teaching - Where do we Stand, where are we Heading? Initial Findings of the Research Project 'Remote Teaching and Adaptation to the Social Conditions under the Coronavirus Pandemic]. Warszawa: ORE. Retrieved 28 February 2021 from: https://ug.edu.pl/news/sites/ug.edu.pl/files.

Reason, P., \& Torbet, W.R. (2001). 'The Action Turn: Toward a Transformational Social Science.' Concepts and Transformations, 6(1), 1-37.

Sachs, J. (1999). Learning to Improve or Improving Learning: The dilemma of Teacher Continuing Professional Development. Retrieved 22 July 2014 from: http://www.fm-kp.si/ zalozba/ISBN/978-961-6573-65-8/009-020.pdf, doi: 10.12775/RA.2013.053.

Siarkiewicz, E., Trębińska-Szumigraj, E., \& Zielińska-Pękał, D. (2012). Edukacyjne prowokacje: Wykorzystanie etnografii performatywnej w procesie ksztatcenia doradców 
METODY ZBIERANIA I ANALIZY DANYCH W BADANIACH EDUKACYJNYCH

[Educational Provocations: Performative Ethnography in Counsellor Training]. Kraków: Oficyna Wydawnicza Impuls.

Žižek, S. (2020). Pandemia! COVID-19 trzesie światem [Originally published as Pandemic! COVID-19 Shakes the World]. Transl. by J. Maksymowicz-Hamann. Gdynia: Wydawnictwo Relacja. 